\title{
Influence of magnesium hydrosilicate on the properties plantar rubber
}

\author{
(C) Konstantin V. Efimov, Lyudmila Yu. Tsareva, \\ Nikolay F. Ushmarin, and Nikolay I. Koltsov* ${ }^{+}$ \\ Department of Fhysical Chemistry and Macromolecular Compounds. Chuvash State University \\ of I.N. Ulyanov. Moskovsky ave., 15. Cheboksary, 428015. Chuvash Republic. Russia. \\ Phone:+7 (8352) 45-24-68.E-mail: koltsovni@mail.ru
}

\begin{abstract}
*Supervising author; ${ }^{+}$Corresponding author Keywords: magnesium hydrosilicate, rossil 175, rubber mixture, plantar rubber, rheometric properties, physical and mechanical properties.
\end{abstract}

\begin{abstract}
The properties of rubber products are determined by the nature and content of caoutchoucs, vulcanizing systems and other ingredients. Among them, fillers play an important role. The most common fillers are carbon black and silicas. Recently, in connection with the increasing operational requirements for rubber products, additives of special fillers began to be introduced into rubber mixtures. Among them, silicates are of practical interest, the use of which allows not only to reduce the cost, but also to give qualitatively new useful physical and mechanical properties to rubbers. Improving the physical and mechanical properties of rubbers directly depends on the particle size of the fillers. Fillers with a smaller particle size have a larger surface area and have a significant effect on the physical and mechanical properties of rubbers. The highly developed surface of powdered magnesium hydrosilicate suggests its use as a filler for rubber compounds. In this regard, it is of interest to study the effect of magnesium hydrosilicate on the properties of rubbers. This article explored the possibility of using magnesium hydrosilicate in plantar rubber based on a combination of nitrile butadiene SKN-4055, methyl styrene butadiene SKMS-30ARK and isoprene SKI-3 caoutchoucs. The rheometric properties were investigated for the rubber mixture, and the physical and mechanical properties, hardness, resistance to thermal aging and the action of aggressive media were determined for vulcanizates. As a result of the studies, it was found that the best rheometric, physico-mechanical and operational properties are possessed by the vulcanizate of the rubber compound, in which the silicon-acid filler of rossil 175 was partially replaced by magnesium hydrosilicate. This rubber can be used in the production of oil and petrol resistant soles of rubber shoes.
\end{abstract}

\section{References}

[1] K.A. Andrianov. Organoelemental Chemistry Methods. Silicon. Moscow: Nauka. 1968. 700p. (russian)

[2] K.A. Andrianov, L.M. Khananashvili. Technology of Organoelement Monomers and Polymers. Moscow: Khimiya. 1973. 400p. (russian)

[3] S.N. Borisov, M.G. Voronkov, E.Ya. Lukevits. Organoelement Compounds. Leningrad: Khimiya. 1966. 554p. (russian)

[4] M.G. Voronkov, E.A. Maletina, V.K. Roman. Heterosiloxanes. Novosibirsk: Nauka. 1984. 269p. (russian)

[5] M.G. Voronkov, N.P. Shapkin. Phosphorus-containing polymetalloorganosiloxanes. Journal of Organometallic Chemistry. 1990. Vol.389. No.2. P.169-186.

[6] V.A. Igonin, O.I. Shchegolikhina, S.V. Lindeman, M.M. Levitsky, Yu.T. Struchkov, A.A. Zhdanov. Novel class of transition metal coordination compounds with macrocyclic organosiloxanolate ligands; their synthesis and crystal structure. Journal of Organometallic Chemistry. 1992. Vol.423. No.3. P.351-360.

[7] L. Rosch, P. John, R. Reitmeier. Silicon Compounds, Organic. Ullmann's Encyclopedia of Industrial Chemistry, Wiley-VCH, Weinheim. 2002. Vol.32. P.637-674.

[8] S. Patai, Z. Rappaport. The Chemistry of Organic Silicon Compounds, 2 vols., Wiley-Interscience, Chichester. 1989. 908p.

[9] T. Kemmit, W. Henderson. A New Route to Silicon Alkoxides from Silica. Australian Journal of Chemistry. 1998. Vol.51. No.11. P.1031-1035. 
[10] H. Cheng, R. Tamaki, R.M. Laine, F. Babonneau, Y. Chujo, D.R. Treadwell. Neutral alkoxysilanes from silica. Journal of the American Chemical Society. 2000. Vol.122. No.41. P.10063-10072. DOI: 10.1021/ja001885h

[11] R.M. Laine, K.Y. Blohowiak, T.R. Robinson, M.L. Hoppe, P. Nardi, J. Kampf, J. Uhm. Synthesis of pentacoordinate silicon complexes from silicon dioxide. Nature. 1991. Vol.353. No.6345. P.642-644. DOI: $10.1038 / 353642 \mathrm{a} 0$

[12] K.Y. Blohowiak, D.R. Treadwell, B.L. Muller, M.L. Hoppe, et al. $\mathrm{SiO}_{2}$ as a Starting Material for the Synthesis of Pentacoordinate Silicon Complexes. Chem. Mater. 1994. Vol.6. No.11. P.2177-2192. DOI: $10.1021 / \mathrm{cm} 00047 \mathrm{a} 045$

[13] L. Sun, K. Gong. Silicon-Based Materials from Rice Husks and Their Applications. Industrial \& Engineering Chemistry Research. 2001. Vol.40. No.25. P.5861-5877. DOI: 10.1021/ie010284b

[14] W. Wang, J.C. Martin, R. Huang, W. Huang, A. Liu, A. Han, L. Sun. Synthesis of silicon complexes from rice husk derived silica nanoparticles. RSC Advances. 2012. Vol.2. No.24. P.9036-9041. DOI: 10.1039/C2RA20986A

[15] N.P. Shapkin, A.E. Panasenko, A.V. Gerasimenko, A.B. Sloboduk, P.S. Dmitrenok, N.A. Didenko. Silicon complexes from rice husk: Synthesis, crystal structure, and properties of 1,2-bissilatranyloxyethane. Silicon. 2018. Vol.11(2). P.1099-1105. https://doi.org/10.1007/s12633-018-9898-9

[16] L.A. Zemnukhova, Yu.M. Nikolenko. Study by X-Ray Photoelectron Spectroscopy of Rice Husk and the Products of Its Processing. Russian Journal of General Chemistry. 2011. Vol.81. No.4. P.694-700.

[17] I. Gutzow, R. Pascova, N. Jordanov, S. Gutzov, I. Penkov, I. Markovska, J.W.P. Schmelzer, F.-P. Ludwig. Structure, Thermodynamic Properties, Solubility and Synthesis of the Different Modifications of Silica. Nucleation Theory and Applications. 2011. P.95-143.

[18] J. Puri, R. Singh, V. Chahal. Silatranes: a review on their synthesis, structure, reactivity and applications. Chemical Society Reviews. 2011. Vol.40. No.3. P.1791-1840.

[19] V.V. Korochentsev, L.B. Leontiev, V.N. Makarov, I.G. Halchenko, N.P. Shapkin, A.L. Shkuratov. Organosilicate antifriction composites based on vermiculite for forming coatings on the friction surfaces of steel parts. Journal of Applied Chemistry. 2014. Vol.87. No.12. P.1727-1734. (russian)

[20] N.P. Shapkin, V.I. Razov; V.V. Korochentsev; E.A. Tokar; S.V. Gardionov; A.E. Panasenko; I.G. Khal'chenko; M.I. Balanov; A.B. Slobodyuk. Study of the structure of polyphenylsiloxanes containing the metal-ions by physical-chemical methods. Journal of Molecular Structure. 2017. Vol.1145. P.300308. DOI: $10.1016 /$ j.molstruc.2017.05.046

[21] A.D. Damaeva. Oligometallophenylsiloxanes and the effect of the nature of the metal on their properties. High-molecular compounds (A). 1982. Vol.24. No.4. P.884-890. (russian)

[22] K. Nakamoto. Infrared and Raman Spectra of Inorganic and Coordination Compounds. 4th Edition. Wiley, New York. 1986. 484 p.

[23] S.V. Gardionov, N.P. Shapkin, M.I. Balanov, V.V. Vasiliev, V.I. Razov, V.O. Trukhin. The study of polymetallorganosiloxanes by X-ray diffractometry and positron annihilation spectroscopy. Journal of Structural Chemistry. 2016. Vol.57. No.3. P.537-541. (russian) 